\title{
Mechanisms and Management of Asthma
}

\section{Exacerbations}

James M. Ramasahai ${ }^{1}$, Philip M. Hansbro ${ }^{1,2}$, Peter A. B. Wark ${ }^{1}$

${ }^{1}$ Priority Research Centre for Healthy Lungs, Hunter Medical Research Institute, University of Newcastle, Newcastle, New South Wales, Australia; ${ }^{2}$ Centre for Inflammation, Centenary Institute and University of Technology Sydney Supported by grants and fellowships from the National Health and Medical Research Council of Australia, the University of Newcastle, and the Hunter Medical Research Institute.

Author Contributions: J.M.R and P.A.B.W conceptualized the review. J.M.R, P.M.H, and P.A.B.W wrote, edited and revised the manuscript.

Correspondence and requests for reprints should be addressed to Peter A. B. Wark, BMed Ph.D., FRACP FThorSoc, Priority Research Centre for Healthy Lungs, Hunter Medical Research Institute, Lot 1 Kookaburra Circuit, New Lambton Heights, Newcastle, New South Wales 2305, Australia. Email: Peter.Wark@hnehealth.nsw.gov.au 


\begin{abstract}
Acute asthma remains an important medical emergency, the most frequent cause of acute admissions in children and a major source of morbidity for adults with asthma. In all ages with asthma the presence of exacerbations is an important defining characteristic of asthma severity. In this review we will assess the epidemiology of acute asthma, the triggers of acute exacerbations and the mechanisms that underlie these exacerbations. We will also assess current treatments that prevent exacerbations, with an emphasis on the role of type 2 airway inflammation in the context of acute exacerbations and the novel treatments that effectively target this. Finally we will review current management strategies of the exacerbations themselves.
\end{abstract}

\title{
Abstract word count: 111
}

Main text word count: 3505 


\section{Introduction}

Acute exacerbations of asthma remain a serious treatment challenge. They are a frequent cause of hospital admission or emergency room (ER) presentation, especially in children and according to the World Health Organisation, asthma was responsible for 383,000 deaths in 2015. Exacerbations are now considered to be key in defining the severity of the disease and their prevention is an important metric to measure success of asthma treatments (1). Definitions of acute asthma or exacerbations have varied over the years, and a more precise definition was required to standardize outcomes in clinical trials and clinical medicine. As a result, the ATS/ERS convened a task force to define exacerbations as well as asthma control (2). Consequently, a severe exacerbation was defined as; the use of corticosteroids for at least 3 days or a hospitalisation or ER visit because of asthma requiring corticosteroids. Moderate exacerbations were defined as an event that required a change in treatment to prevent it from becoming severe and not severe enough to warrant oral corticosteroids (OCS).

The interventions available for use in the setting of acute asthma are relatively limited, and the management of asthma exacerbations varies depending on severity and the treatment setting. Since the 1960s treatment for acute asthma has focused on the use of systemic corticosteroids and selective beta- 2 agonists, and unfortunately there have been few new treatments trialled and little added of particular efficacy to the armamentarium of acute management with the exception of supportive measures. The treatment of asthma exacerbation currently begins with asthma selfmanagement in the outpatient setting. As the severity of the presentation escalates, so do treatment regimens and the support required. Here we review the mechanisms that underpin acute asthma and its management. 


\section{What causes acute exacerbations}

\section{Epidemiology}

Malcolm Sears succinctly summarized the data that describes the epidemiology of acute asthma, emphasizing the importance of age, sex and seasonality (Figure 1)(3). Acute asthma remains predominantly a disease of early childhood, with more boys affected before puberty, and then a switch occurs where females are more likely to suffer with acute asthma that persists throughout life. There is a peak of events when children return to school in autumn, with younger children and adults experiencing less pronounced increases following this and a smaller peak that occurs in those over 50 years in midwinter, with both of these peaks associated with the presence of virus infections (3).

These events seem to hold true across the developed world and are well illustrated by Australian data (4). The problem is greatest in childhood, with children being hospitalized at a prevalence of $495 / 100,000$, compared to adults at $92 / 100,000$. Deaths from asthma though were rare in 2016 with only 455 and two thirds of these were in those aged greater than 75 years. This epidemiological data also demonstrates how much asthma is also a disease of the social environment. In Australia, despite universal public healthcare the prevalence of acute asthma was higher in populations with a lower socioeconomic background, was two-fold greater amongst indigenous communities and higher in adults living in remote areas (4). Outcomes of studies of the relationships between asthma incidence and lower socioeconomic status (SES) have varied from no relationship (5) to increased risk (6). In general while asthma tends to be a disease of the developed world, explained in part through the hygiene hypothesis, when present, poverty is nearly always associated with worse outcomes (7). Lower SES has consistently been shown to be an independent risk for poor asthma control and exacerbations $(8,9)$ even when complicated by ethnicity (10). In developing nations, poverty or low SES is similarly associated with poor asthma 
outcomes (11). The reasons for this are likely to be complex, including poor nutrition, access to health care, affordability of medicine, and exposure to cigarette smoke and/or pollution (7). While easy to dismiss as a problem to be solved by government and changes in social policy, well conducted, patient-centred interventions that focus on self-management can successfully deliver improved outcomes including reducing exacerbations (12).

\section{Triggers for acute asthma}

The seasonal variation in asthma exacerbations especially in children has already been described, particularly the marked increase that accompanies the return to school in Autumn. This has been linked strongly with the presence of rhinovirus (RV) infection and lack of preventer use in Canadian children aged 5-15 years (13). Less intense peaks have also been seen in mid-winter in older adults and patients with chronic obstructive pulmonary disease and associated with influenza (14). While other factors contribute to this seasonal variation in acute asthma, in schoolage children, the community prevalence of $\mathrm{RV}$ is the strongest predictor (15). Associations between respiratory infections and acute asthma has been recognised for centuries, as described in 1864 by Henry Salter (himself an asthmatic) "the most prominent and frequent of all exciting causes is what is commonly called taking cold ... The asthma consequent on cold on the chest (bronchitis) is of a most painful and distressing kind; unlike that produced by cold directly, it often lasts for days". The ability to identify viruses by polymerase chain reactions (PCR), demonstrated that they were associated with $80-85 \%$ of asthma exacerbations in children (16) and the majority in adults (17), with RV the most common. While true to Salter's description exacerbations associated with viral infections have also been shown to cause more severe disease (18).

Recently it has been shown that certain RV strains are more closely linked to acute asthma. In children the newly identified RV-C strain was detected in $59.4 \%$ and was associated with more severe disease (19). In childhood, RV-C strains seem particularly capable of causing exacerbations, 
while infections with RV-A strains require a higher viral titre to trigger an exacerbation, whereas RV-B strains seem relatively benign (20). RV-C binds to epithelial cells via the cadherin-related family member 3 protein, with a missense single nucleotide polymorphism (rs6967330, C529Y) linked to greater cell-surface expression (21). This mutation has also been linked to childhood severe asthma exacerbations (22), and recently this enhanced risk was found to be due to RV-C associated exacerbations in two separate birth cohorts (23). While this strong association has been seen in children with acute asthma and RV-C, it does not seem to hold true for adults where RV-A dominates and RV-C was rarely identified in Australian (24) and US cohorts (25).

Environmental factors also influence asthma exacerbations. A Canadian study showed that after adjusting for season and air pollution a doubling in grass pollen levels and fungal spore counts increased asthma admissions (26). A US study also showed a potential relationship between mould spore levels and asthma deaths (27), and a metanalysis linked outdoor pollen exposure to acute asthma events (28). More recently an Australian study demonstrated three separate peaks of asthma admissions, the first two related to virus infection, but the third in late spring correlated with high grass pollen counts and high humidity, implicating thunderstorms as a trigger (29). Acute thunderstorm asthma events are extreme examples of this phenomena, where high pollen counts combine with atmospheric conditions that induce severe acute asthma epidemics (30,31), associated with intense type 2 airway inflammation (32)(Figure 1).

\section{Exacerbation prone asthma phenotype}

Within populations the risk of asthma exacerbations is not equal. In children a history of previous severe exacerbations appears to be the strongest predictor along with poor asthma symptom control and disease severity (33-35). This risk though appears to vary by season, with exacerbations occurring in autumn and winter (usually viral) predicted by a history of previous 
exacerbations, and those in spring and summer by dose of inhaled corticosteroids (ICS) required for control (36). This suggests that events triggered by allergy may be better controlled by regular use of ICS.

In adults, analysis of three clinical trials of greater than 7,000 subjects with asthma who had their treatment with ICS/long acting beta-agonist (LABA) therapy optimized, exacerbations were predicted by disease severity, asthma symptom control and a history of smoking (37). Unlike in childhood, in adults, comorbid disease is also an important additional factor. This has been consistently seen with chronic rhinosinusitis, body mass index, and psychological dysfunction (38, 39). In adults with severe asthma the complexity of this situation needs to be appreciated if effective strategies are to be designed to prevent exacerbations. Using registry data McDonald et al., demonstrated that 24 individual treatable traits could be identified in the domains of; pulmonary, extrapulmonary and behavioural factors that were over represented in those with severe asthma and were related to risk of exacerbation (40). In the context of severe asthma a single approach that only focuses on asthma disease control then is unlikely to be sufficient to improve patient outcomes.

\section{Poor asthma control and type 2 airway inflammation in acute asthma}

One key independent factor that emerges as an ongoing risk for exacerbations and provides insight into the pathophysiology of acute asthma is the presence of refractory type 2 airway inflammation. Type 2 inflammation is characterized by the release of the cytokines interleukin (IL)-5, IL-4 and IL-13 produced by T-helper type-2 (Th2) cells and innate lymphoid cells of type 2 (ILC2 cells) and is associated with airway eosinophilia and elevated levels of exhaled nitric oxide.

Assessing subjects with both severe asthma as well as mild to moderate disease; severity and asthma symptom control independently predicted exacerbation risk, but so too did sputum eosinophilia or elevated exhaled nitric oxide (41). While adult onset asthma is often not associated 
with atopy, a large number, especially those with more severe disease have evidence of type 2 immune activation, with elevated sputum eosinophils and increased levels of exhaled nitric oxide (42). More recently blood eosinophils have been identified as a good predictor of airway eosinophils (43). In population samples of adults, elevated blood eosinophils are associated with increased risk of exacerbations. In 2,392 subjects with asthma, a blood eosinophil count of $>0.4$ $\mathrm{x} 10^{9} / \mathrm{ml}$ independently predicted exacerbation risk with an odds ratio of $1.31(95 \% \mathrm{Cl} 1.07$ to 1.6$)$ (44). This remained an independent predictor for exacerbations, even in those with poor asthma symptom control (45), and showed the strongest association with the most severe exacerbations that result in hospital admission (odds ratio; $5.14,95 \% \mathrm{Cl}, 1.76$ to 14.99 ) (46). Combining elevated blood eosinophils together with exhaled nitric oxide may further define those at greatest risk of future asthma exacerbations (47). The presence of active type 2 airway inflammation and its measurement with biomarkers, such as blood eosinophils and exhaled nitric oxide provides a clear indication of risk for future exacerbations.

\section{Non-type 2 airway inflammation in acute asthma}

While the role of type 2 airway inflammation in acute asthma is becoming much clearer, other immune processes are likely to also be important and future treatments will likely rely upon a clearer understanding of these (48). Acute exacerbations, especially those associated with virus infection have been shown to be associated with neutrophilic inflammation (49), though this may differ in children where there is more evidence of eosinophilic inflammation (50). Dysregulation of innate immune responses, including activation of inflammasome pathways and airway neutrophila have been seen to be distinct in asthma with non-type 2 inflammation $(51,52)$, with recent mechanistic and clinical studies implicating non-type 2 airway inflammatory mechanisms play a key role in exacerbations, with microRNAs and inflammasomes more likely involved in virus infection as well as contributing to corticosteroid resistant processes $(53,54)$. 


\section{Management of exacerbations}

\section{Controlling type 2 airway inflammation}

Control of type 2 airway inflammation is critical in preventing exacerbations (Table 1). Treatment with ICS remains the cornerstone strategy for the majority with asthma and is effective in most at reducing the risk of exacerbations, including the risk of death (55-57). Using either OCS or ICS, adjusted to suppress airway eosinophilia in asthma has been shown to effectively reduce the risk of exacerbations $(58,59)$. More recently biologic treatments that target specific aspects of type 2 immune responses in those with severe asthma and ICS refractory type 2 airway inflammation have been shown to reduce asthma exacerbations. Treatment of patients with severe allergic asthma with Omalizumab, a monoclonal antibody to IgE, reduces exacerbations in those with severe disease despite optimal doses of ICS/long acting beta-agonist (60). In subjects with severe asthma and refractory eosinophilia, monoclonal antibody therapy against IL-5 reduced exacerbation frequency by approximately half (61). While treatment with Dupilumab, a monoclonal therapy against IL-4 and IL-13, similarly reduced asthma exacerbations though only in those with persistent type 2 airway inflammation, as measured by either increased blood eosinophils or exhaled nitric oxide, despite treatment with ICS $(62,63)$.

\section{Adjusting ICS/OCS}

Control of type 2 airway inflammation prevents exacerbations, but also improves outcomes during an exacerbation. Treatment with systemic steroids, including 1-6 days of prednisone or dexamethasone, effectively reduced relapse rates in acute asthma in children (64). Similarly, in adults, systemic steroids reduced acute relapse rates, though the course of prednisone needed to be at least 7-10 days in duration, with shorter courses being ineffective 
(65). Treatment with ICS cannot be used in place of OCS (66), but may prevent the need to use

OCS in acute asthma. Quon et al., showed that doubling the maintenance dose of ICS at the start of an exacerbation was insufficient to prevent the use of OCS (67). More recently, however, Oborne et al., assessed whether a quadruple dose of ICS could prevent exacerbations needing OCS (68). Although they failed to reach their primary outcome, possibly because their platform event filler-triggered action plan provided a delayed response, those who did increase their ICS used less OCS.

A more flexible approach that adjusted ICS dose in response to symptoms has been shown to be more successful. Formoterol/budesonide combinations have shown utility in the setting of mild asthma exacerbations and loss of asthma control when used as maintenance and reliever therapy (69). The formoterol component in Symbicort has a rapid onset of action of 1-3 minutes and also a prolonged duration of action (70). The short onset of action is particular to formoterol containing inhalers, and allows it to be used as reliever therapy. This has a role in the setting of mild asthma exacerbations, where, instead of typical short acting bronchodilators, formoterol/budesonide combination inhalers lead to symptomatic bronchodilation along with the administration of extra ICS. Ideally, this extra ICS may be sufficient to target steroid-responsive inflammation that may be at the heart of the current exacerbation. As a result, adjustable dosing of budesonide formoterol is linked with better exacerbation control long-term (71). More recently this approach was used to show that as required use of Formoterol/budesonide, in those with mild intermittent disease also effectively reduced exacerbations and the need for OCS $(72,73)$.

Definitive treatment in the setting of severe exacerbations currently involves therapy with OCS. Their use is associated with reduced recurrent asthma exacerbations, and emergency department and hospital admissions (74). Given that exacerbations are thought to often involve eosinophilic inflammation beyond what is typically managed with maintenance therapy in the patient's day-to-day life, systemic corticosteroids effectively target this inflammation. They have 
been shown to induce apoptosis in eosinophils, reduce mucus hypersecretion in the airways and prevent the recruitment of eosinophils. All of this contributes to their importance as a major therapy in the treatment of acute asthma exacerbations (75).

\section{Self-management}

The Global Strategy for Asthma Management and Prevention (GINA), along with most international respiratory societies, recommend self-management strategies to reduce the impact of acute exacerbations in all groups (1). This involves patient education and the provision of an individualised written asthma action plan. An action plan should include a description of regular maintenance therapy, and instructions for the escalation of therapy depending on either a worsening of symptoms or a change in peak flow monitoring (for examples see https://www.nationalasthma.org.au/health-professionals/asthma-action-plans/asthma-actionplan-library). Action plans that include instructions using 2-4 action points and the use of both ICS and when to initiate OCS improved health outcomes including reductions in hospital admissions (76).

\section{Bronchodilators}

Since the advent of metered dose inhalers for the treatment of bronchoconstriction, betaadrenergic bronchodilators have formed the mainstay of treatment of acute exacerbations. In the outpatient setting, patients are instructed to increase their use of short-acting bronchodilators in conjunction with their symptoms. Given their potential to mask symptoms and delay seeking of medical attention, it is important to adequately educate patients on the need to pursue further treatment, typically with increasing doses of corticosteroids (77). While important during the 
acute management of the symptoms of an exacerbation, typically bronchodilators do not treat the underlying inflammation that underpin the exacerbation, particularly eosinophilic inflammation.

Because of their short onset of action, short-acting bronchodilators are used in this setting, most commonly beta-2-agonists but also short-acting anti-muscarinics. Both act on airway smooth muscle to promote bronchodilation. This is mediated by beta-adrenergic stimulation of smooth muscle to enact bronchodilation or cholinergic antagonism to relieve bronchial constriction that is under parasympathetic activity $(78,79)$. Treatment is primarily symptomatic, as bronchodilation does not target the underlying inflammation that drives the exacerbation.

\section{Magnesium}

Typically, the use of magnesium sulfate is limited to those situations where asthma exacerbation is refractory to treatment with bronchodilators and steroids alone. Parenteral administration is used as it has greater bioavailability compared to oral magnesium (80). A Cochrane review demonstrated reduced hospital admissions and a small improvement in lung function with the use of magnesium sulfate in the emergency department (81). A review by Ling et al., did not demonstrate any reduction in hospital admissions with the use of nebulized magnesium, and thus there is not a clear benefit of nebulised administration at this point (82). Another Cochrane review assessed comparisons between the administration of inhaled magnesium sulfate and b2-agonist with b2-agonist alone also did not show any improvement in lung function or hospital admission rate (83). These findings seem to be equivalent in children (84).

\section{Treating infection and non-type 2 inflammation}

Infection plays a crucial role in triggering acute asthma. Experimental studies show impaired innate immune responses to virus infections in asthma (85), and that infections induce microRNAs and inflammasome activation that suppress responses to corticosteroids $(53,54)$. 
Investigators sought to determine if treatment at the time of a cold with nebulised interferon would reduce exacerbation severity in those with a history of virus-induced acute asthma.

Treatment though did not improve the severity of acute asthma symptoms overall, except in those with pre-existing poor control and more severe disease (86). In contrast to acute exacerbations of COPD, there is no evidence that antibiotics improve outcomes in acute asthma (87). This is likely since the majority of exacerbations are associated with viral infections. Macrolide antibiotics have been used to reduce the frequency of exacerbations of asthma and other airways disease and are proposed to have anti-inflammatory effects. In a trial of 278 adults with asthma treatment with the ketolide Telithromycin was shown to improve asthma symptom scores (88), but it was later withdrawn due to toxicity. A similar trial attempted to assess add on azithromycin to see if this would improve asthma symptoms acutely, the trial failed to demonstrate a difference, though the investigators had to exclude 10 subjects for everyone randomised as they had already received antibiotics (89). Azithromycin has also been used in preschool children (1-3 years) presenting with acute wheezing illnesses, but has had mixed results, with one trial demonstrating a reduction in length of symptoms (90), and another failing to show improvement in clinical outcomes (91). Antimicrobials, instead, should be reserved for those cases where there is clinical suspicion for bacterial infection that would require treatment in conjunction with treatment of the asthma exacerbation (1).

In terms of preventing exacerbations targeting non-type 2 immune mechanisms there have been mixed results (Table 2). In adults with moderate to severe asthma regular azithromycin reduced exacerbation risk in those with and without eosinophilic airway inflammation in an Australian study (92), but not in a European study (93). Tiotropium a long acting anticholinergic bronchodilator has also been shown to reduce exacerbation risk in those on ICS/LABA, in adults and children with asthma, while long acting beta agonists alone have not (94). Omalizumab as discussed reduces exacerbations, but recent evidence suggests part of its effect may be by 
improving antiviral immune responses (95). However monoclonal antibodies that targeted $\mathrm{TH}-17$

(96) and tumour necrosis factor-alpha (97) failed to reduce exacerbations.

\section{Conclusions}

Treatment of asthma exacerbations using the therapies described is successful for a large proportion of patients. Indeed, as a result, over the course of the last 100 years, the mortality rate from asthma exacerbations has declined considerably. This has largely been due to the recognition of corticosteroids as a cornerstone of treatment of asthma exacerbations. Despite these improvements, there remains a significant ongoing mortality rate due to asthma that appears to have reached a plateau in the developed world. With the advent of precision medicine and targeted therapies, there have been many new insights into the management of chronic disease in asthma, however, this has not yet been seen with exacerbations. We remain hopeful that further advances will see further decline in mortality due to asthma - whether this be due to advances in chronic therapy, acute and exacerbation management, or even, potentially, cure. 
Table 1 Preventing acute asthma

\begin{tabular}{|c|c|c|c|c|}
\hline Therapeutic & $\begin{array}{l}\text { Mechanism of } \\
\text { action }\end{array}$ & Clinical effect & Asthma phenotype & References \\
\hline ICS & $\begin{array}{l}\text { Effective in control } \\
\text { of type } 2 \text { airway } \\
\text { inflammation, } \\
\text { probable effects on } \\
\text { non-specific } \\
\text { features of } \\
\text { inflammation. }\end{array}$ & $\begin{array}{l}\text { Reduced } \\
\text { exacerbations, } \\
\text { improved asthma } \\
\text { symptoms, } \\
\text { reduced airway } \\
\text { reactivity. }\end{array}$ & $\begin{array}{l}\text { Arguably effective } \\
\text { in all with asthma, } \\
\text { effect clearly } \\
\text { greatest in those } \\
\text { with Type } 2 \\
\text { immune activation. }\end{array}$ & $\begin{array}{l}(56,64-68,74, \\
75,98,99)\end{array}$ \\
\hline Omalizumab & $\begin{array}{l}\text { Monoclonal } \\
\text { antibody against } \\
\text { IgE, prevents IgE } \\
\text { crosslinking and } \\
\text { allergen induced } \\
\text { activation. In-vitro } \\
\text { evidence that it } \\
\text { improves antiviral } \\
\text { responses in } \\
\text { plasmacytoid } \\
\text { dendritic cells. }\end{array}$ & $\begin{array}{l}\text { Reduced } \\
\text { exacerbations, } \\
\text { improved asthma } \\
\text { symptoms. }\end{array}$ & $\begin{array}{l}\text { Moderate to severe } \\
\text { allergic asthma, } \\
\text { poor control or } \\
\text { exacerbations } \\
\text { despite ICS/LABA. }\end{array}$ & $(95,99-101)$ \\
\hline $\begin{array}{l}\text { Therapies that } \\
\text { target IL-5 } \\
\text { pathways } \\
\text { (Mepolizumab, } \\
\text { Benzralizumab, } \\
\text { Reslizumab) }\end{array}$ & $\begin{array}{l}\text { Monoclonal } \\
\text { antibody that } \\
\text { blocks the action of } \\
\text { IL-5 on recruitment } \\
\text { of immune cells, in } \\
\text { particular } \\
\text { eosinophils }\end{array}$ & $\begin{array}{l}\text { Reduced } \\
\text { exacerbations, } \\
\text { improved asthma } \\
\text { symptoms. }\end{array}$ & $\begin{array}{l}\text { Severe asthma with } \\
\text { refractory } \\
\text { eosinophilic } \\
\text { inflammation } \\
\text { despite ICS }\end{array}$ & (61) \\
\hline Dupilumab & $\begin{array}{l}\text { Monoclonal } \\
\text { antibody that } \\
\text { blocks the action of } \\
\text { IL- } 4 / 13 \text {. }\end{array}$ & $\begin{array}{l}\text { Reduced } \\
\text { exacerbations, } \\
\text { improved asthma } \\
\text { symptoms, } \\
\text { improved lung } \\
\text { function. }\end{array}$ & $\begin{array}{l}\text { Moderate to severe } \\
\text { asthma, with } \\
\text { evidence of active } \\
\text { type } 2 \text { airway } \\
\text { inflammation, } \\
\text { either elevated } \\
\text { exhaled nitric oxide } \\
\text { or blood } \\
\text { eosinophils. }\end{array}$ & $(62,63)$ \\
\hline Tezepelumab & $\begin{array}{l}\text { Monoclonal } \\
\text { antibody that } \\
\text { blocks the action of } \\
\text { TSLP. }\end{array}$ & $\begin{array}{l}\text { Reduced } \\
\text { exacerbations, } \\
\text { improved lung } \\
\text { function }\end{array}$ & $\begin{array}{l}\text { Adults with } \\
\text { moderate to severe } \\
\text { asthma, at this } \\
\text { stage not limited to } \\
\text { an inflammatory } \\
\text { phenotype (based } \\
\text { on } 1 \mathrm{RCT} \text { ). }\end{array}$ & (102) \\
\hline Tiotropium & $\begin{array}{l}\text { Long acting } \\
\text { antimuscarinic } \\
\text { agent, blocking the } \\
\text { action of } \\
\text { acetylcholine on } \\
\text { airway smooth } \\
\text { muscle and goblet }\end{array}$ & $\begin{array}{l}\text { Reduced } \\
\text { exacerbations, } \\
\text { improved lung } \\
\text { function and } \\
\text { asthma symptoms }\end{array}$ & $\begin{array}{l}\text { Recommended in } \\
\text { those }>12 \text { years as } \\
\text { add on to ICS/LABA, } \\
\text { may be effective in } \\
\text { those with milder } \\
\text { disease }\end{array}$ & (94) \\
\hline
\end{tabular}




\begin{tabular}{|c|c|c|c|c|}
\hline & $\begin{array}{l}\text { cells. Anti- } \\
\text { inflammatory and } \\
\text { effects on } \\
\text { neurogenic } \\
\text { remodelling have } \\
\text { been proposed. }\end{array}$ & & & \\
\hline Azithromycin & $\begin{array}{l}\text { Macrolide } \\
\text { antibiotic, with } \\
\text { potential anti- } \\
\text { inflammatory } \\
\text { effects }\end{array}$ & $\begin{array}{l}\text { Mixed results. May } \\
\text { reduce } \\
\text { exacerbation } \\
\text { frequency. }\end{array}$ & $\begin{array}{l}\text { Adults with } \\
\text { moderate to severe } \\
\text { asthma, not limited } \\
\text { to those with type } \\
2 \text { immune } \\
\text { activation. }\end{array}$ & $(92,93)$ \\
\hline
\end{tabular}

Table 1: ICS (inhaled corticosteroid) LABA (long acting beta agonist). 
Table 2 Treating acute asthma

\begin{tabular}{|c|c|c|c|c|}
\hline & Class & Example & Effect & References \\
\hline SABA/SAMA & $\begin{array}{l}\text { 1. Inhaled } \\
\text { bronchodilator }\end{array}$ & $\begin{array}{l}\text { Salbutamol MDI } \\
\text { (100mcg/puff) 2-4 puffs q1h } \\
\text { PRN } \\
\text { Atrovent MDI (17mcg/puff) } 2 \\
\text { puffs q4h PRN } \\
\text { (up to q20min in ED acutely) }\end{array}$ & $\begin{array}{l}\text { Symptomatic relief: Beta-2- } \\
\text { agonist leading to smooth } \\
\text { muscle cell relaxation } \\
\text { allowing for bronchodilation } \\
\text { Anti-cholinergic relieves } \\
\text { parasympathetic } \\
\text { bronchoconstriction }\end{array}$ & (79) \\
\hline $\begin{array}{l}\text { ICS/LABA or } \\
\text { ICS }\end{array}$ & $\begin{array}{l}\text { 2. Inhaled } \\
\text { corticosteroid }\end{array}$ & $\begin{array}{l}\text { Budesonide/formoterol via } \\
\text { dry powder device } \\
\text { (200/6mcg) } 1-2 \text { puffs as } \\
\text { needed (max. } 8 / \text { day) } \\
\text { Ciclesonide (160) } 4 \text { puffs TID }\end{array}$ & $\begin{array}{l}\text { Treat steroid-responsive } \\
\text { inflammation in mild to } \\
\text { moderate asthma } \\
\text { exacerbations. Potentially } \\
\text { avoids the necessity of } \\
\text { systemic corticosteroids. }\end{array}$ & $(68,69,72,73)$ \\
\hline Oral steroids & $\begin{array}{l}\text { 2. Systemic } \\
\text { corticosteroid }\end{array}$ & $\begin{array}{l}\text { Adults Prednisone } 37.5 \text { to } \\
50 \mathrm{mg} \text { daily for } 7 \text { days } \\
\text { Children }>6 \text { years give } \\
\text { prednisone } 1 \mathrm{mg} / \mathrm{kg} \\
\text { (maximum } 50 \mathrm{mg} \text { ) orally for } 3 \\
\text { days. }\end{array}$ & $\begin{array}{l}\text { Treat steroid-responsive } \\
\text { inflammation in asthma } \\
\text { exacerbation. Reduces } \\
\text { relapse and hospitalization } \\
\text { rates. }\end{array}$ & $(64,65,74)$ \\
\hline Magnesium & $\begin{array}{l}\text { 3. Elemental } \\
\text { magnesium }\end{array}$ & $\begin{array}{l}\text { Magnesium sulfate } 2 \mathrm{~g} \text { IV over } \\
20 \text { minutes }\end{array}$ & $\begin{array}{l}\text { Smooth muscle } \\
\text { relaxation/bronchodilation }\end{array}$ & (81) \\
\hline
\end{tabular}

Table 2: Summary of treatment modalities for asthma exacerbation. In the acute setting, the use of Class 1 medications for symptom relief is standard, in addition to Class 2 to target inflammation at the heart of an acute exacerbation and prevent relapse. Class 3 medications are typically used in refractory situations, or where there is clinical need for treatment of comorbidities or ongoing supportive management. SABA (Short acting bronchodilator), SAMA (short acting antimuscarinic). ICS (inhaled corticosteroid) LABA (long acting beta agonist). 


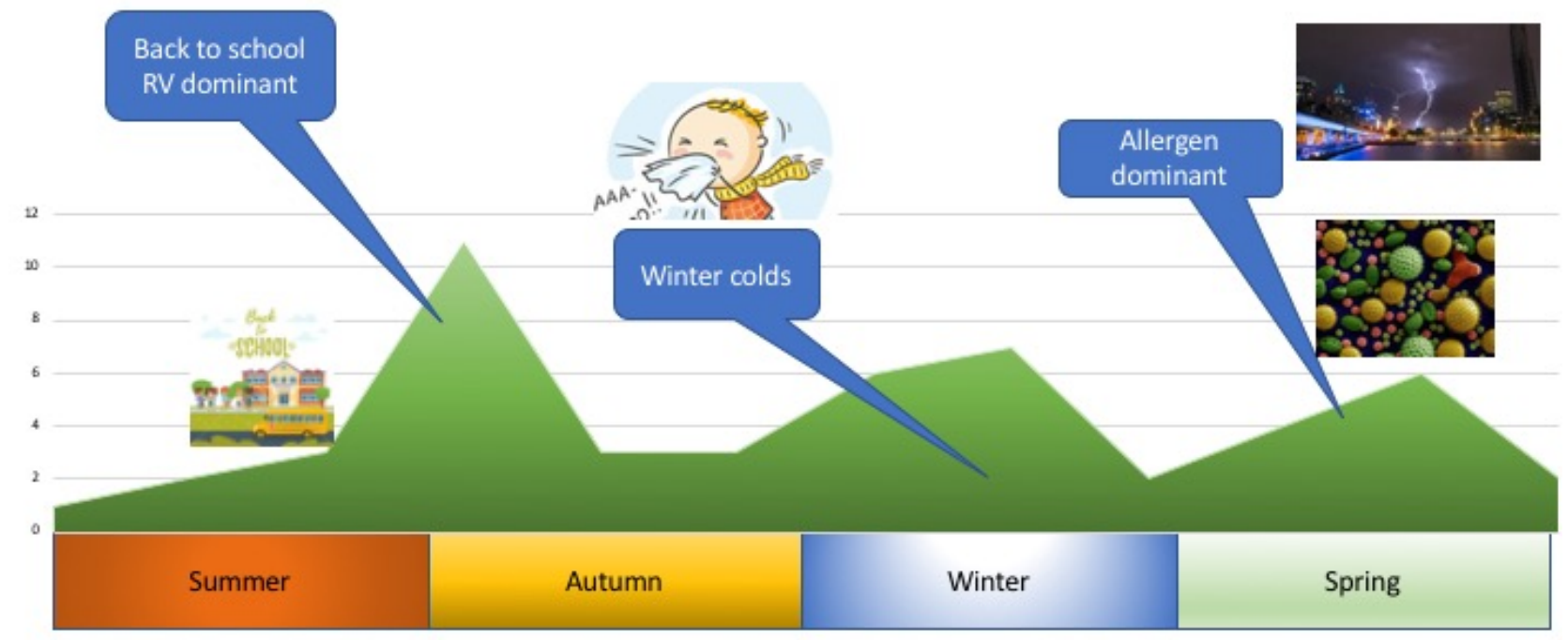

\section{Legend Figure 1}

Figure 1: Acute exacerbations of asthma follow a pattern of seasonal variation. A number of peaks of acute asthma activity occurs. There is a marked increase that accompanies the return to school in Autumn. This has been linked strongly with the presence of rhinovirus (RV) infection and lack of preventer use in school children with asthma. A less intense peak has also been seen in mid-winter in older adults and patients with chronic obstructive pulmonary disease and associated with influenza and other winter related respiratory tract infections. Exposure to allergens however is also important. After adjusting for season and air pollution a doubling in grass pollen levels and fungal spore counts is also associated with increased asthma admissions. This is associated with a third peak in late spring correlated with high grass pollen counts and high humidity, seen through a combination of high ambient pollen counts and weather events like thunderstorm. 


\section{References}

1. Asthma GIf. 2018 GINA Report, Global Strategy for Asthma Management and Prevention. https://ginasthma.org/2018-gina-report-global-strategy-for-asthma-management-andprevention/; 2018.

2. Reddel HK, Taylor DR, Bateman ED, Boulet LP, Boushey HA, Busse WW, Casale TB, Chanez P, Enright PL, Gibson PG, de Jongste JC, Kerstjens HA, Lazarus SC, Levy ML, O'Byrne PM, Partridge MR, Pavord ID, Sears MR, Sterk PJ, Stoloff SW, Sullivan SD, Szefler SJ, Thomas MD, Wenzel SE. An official American Thoracic Society/European Respiratory Society statement: asthma control and exacerbations: standardizing endpoints for clinical asthma trials and clinical practice. Am J Respir Crit Care Med 2009; 180: 59-99.

3. Sears MR. Epidemiology of asthma exacerbations. J Allergy Clin Immunol 2008; 122: 662-668. 4. Chronic respiratory diseases in Australia. Canberra: Australian Institute of Health and Welfare; 2005.

5. Hancox RJ, Milne BJ, Taylor DR, Greene JM, Cowan JO, Flannery EM, Herbison GP, McLachlan CR, Poulton R, Sears MR. Relationship between socioeconomic status and asthma: a longitudinal cohort study. Thorax 2004; 59: 376-380.

6. Hedlund U, Eriksson K, Ronmark E. Socio-economic status is related to incidence of asthma and respiratory symptoms in adults. Eur Respir J 2006; 28: 303-310.

7. Cruz AA, Bateman ED, Bousquet J. The social determinants of asthma. Eur Respir J 2010; 35: 239-242.

8. Bacon SL, Bouchard A, Loucks EB, Lavoie KL. Individual-level socioeconomic status is associated with worse asthma morbidity in patients with asthma. Respiratory Research 2009; 10: 125-125.

9. Aligne CA, Auinger P, Byrd RS, Weitzman M. Risk factors for pediatric asthma. Contributions of poverty, race, and urban residence. Am J Respir Crit Care Med 2000; 162: 873-877.

10. Thakur N, Oh SS, Nguyen EA, Martin M, Roth LA, Galanter J, Gignoux CR, Eng C, Davis A, Meade $\mathrm{K}$, LeNoir MA, Avila PC, Farber HJ, Serebrisky D, Brigino-Buenaventura E, Rodriguez-Cintron W, Kumar R, Williams LK, Bibbins-Domingo K, Thyne S, Sen S, Rodriguez-Santana JR, Borrell LN, Burchard EG. Socioeconomic status and childhood asthma in urban minority youths. The GALA II and SAGE II studies. Am J Respir Crit Care Med 2013; 188: 1202-1209.

11. Cooper PJ, Rodrigues LC, Cruz AA, Barreto ML. Asthma in Latin America: a public heath challenge and research opportunity. Allergy 2009; 64: 5-17.

12. Fox P, Porter PG, Lob SH, Boer JH, Rocha DA, Adelson JW. Improving asthma-related health outcomes among low-income, multiethnic, school-aged children: results of a demonstration project that combined continuous quality improvement and community health worker strategies. Pediatrics 2007; 120: e902-911.

13. Johnston NW, Johnston SL, Duncan JM, Greene JM, Kebadze T, Keith PK, Roy M, Waserman S, Sears MR. The September epidemic of asthma exacerbations in children: A search for etiology. Journal of Allergy and Clinical Immunology 2005; 115: 132-138.

14. Johnston NW, Sears MR. Asthma exacerbations . 1: epidemiology. Thorax 2006; 61: 722-728. 15. Eggo RM, Scott JG, Galvani AP, Meyers LA. Respiratory virus transmission dynamics determine timing of asthma exacerbation peaks: Evidence from a population-level model. Proc Natl Acad Sci U S A 2016; 113: 2194-2199.

16. Johnston SL, Pattemore PK, Sanderson G, Smith S, Campbell MJ, Josephs LK, Cunningham A, Robinson BS, Myint SH, Ward ME, Tyrrell DA, Holgate ST. The relationship between upper respiratory infections and hospital admissions for asthma: a time-trend analysis. Am J Respir Crit Care Med 1996; 154: 654-660.

17. Nicholson KG, Kent J, Ireland DC. Respiratory viruses and exacerbations of asthma in adults.

BMJ 1993; 307: 982-986. 
18. Wark PAB, Simpson J, Saltos N, Slater S, Hensley MJ, Gibson PG. Induced sputum Eosinophils, neutrophils and bronchiectasis in allergic bronchopulmonary aspergillosis. Eur Respir J 2000; 16: 1095-1101.

19. Bizzintino J, Lee WM, Laing IA, Vang F, Pappas T, Zhang G, Martin AC, Khoo SK, Cox DW, Geelhoed GC, McMinn PC, Goldblatt J, Gern JE, Le Souef PN. Association between human rhinovirus $C$ and severity of acute asthma in children. Eur Respir J 2011; 37: 1037-1042.

20. Zheng SY, Wang LL, Ren L, Luo J, Liao W, Liu EM. Epidemiological analysis and follow-up of human rhinovirus infection in children with asthma exacerbation. J Med Virol 2018; 90: 219-228. 21. Bochkov YA, Watters K, Ashraf S, Griggs TF, Devries MK, Jackson DJ, Palmenberg AC, Gern JE. Cadherin-related family member 3 , a childhood asthma susceptibility gene product, mediates rhinovirus C binding and replication. Proc Natl Acad Sci U S A 2015; 112: 5485-5490.

22. Bonnelykke K, Sleiman $P$, Nielsen K, Kreiner-Moller E, Mercader JM, Belgrave D, den Dekker $H T$, Husby A, Sevelsted A, Faura-Tellez G, Mortensen L, Paternoster L, Flaaten R, Molgaard A, Smart DE, Thomsen PF, Rasmussen MA, Bonas-Guarch S, Holst C, Nohr EA, Yadav R, March ME, Blicher T, Lackie PM, Jaddoe VW, Simpson A, Holloway JW, Duijts L, Custovic A, Davies DE, Torrents D, Gupta R, Hollegaard MV, Hougaard DM, Hakonarson H, Bisgaard H. A genome-wide association study identifies CDHR3 as a susceptibility locus for early childhood asthma with severe exacerbations. Nat Genet 2014; 46: 51-55.

23. Bonnelykke K, Coleman AT, Evans MD, Thorsen J, Waage J, Vissing NH, Carlsson CJ, Stokholm J, Chawes BL, Jessen LE, Fischer TK, Bochkov YA, Ober C, Lemanske RF, Jr., Jackson DJ, Gern JE, Bisgaard H. Cadherin-related Family Member 3 Genetics and Rhinovirus C Respiratory IIInesses. Am J Respir Crit Care Med 2018; 197: 589-594.

24. Wark PA, Tooze M, Powell H, Parsons K. Viral and bacterial infection in acute asthma and chronic obstructive pulmonary disease increases the risk of readmission. Respirology 2013; 18: 996-1002.

25. Miller EK, Linder J, Kraft D, Johnson M, Lu P, Saville BR, Williams JV, Griffin MR, Talbot HK. Hospitalizations and outpatient visits for rhinovirus-associated acute respiratory illness in adults. $J$ Allergy Clin Immunol 2016; 137: 734-743 e731.

26. Dales RE, Cakmak S, Judek S, Dann T, Coates F, Brook JR, Burnett RT. Influence of outdoor aeroallergens on hospitalization for asthma in Canada. J Allergy Clin Immunol 2004; 113: 303-306. 27. Targonski PV, Persky VW, Ramekrishnan V. Effect of environmental molds on risk of death from asthma during the pollen season. J Allergy Clin Immunol 1995; 95: 955-961.

28. Erbas B, Jazayeri M, Lambert KA, Katelaris CH, Prendergast LA, Tham R, Parrodi MJ, Davies J, Newbigin E, Abramson MJ, Dharmage SC. Outdoor pollen is a trigger of child and adolescent asthma emergency department presentations: A systematic review and meta-analysis. Allergy 2018; 73: 1632-1641.

29. Silver JD, Sutherland MF, Johnston FH, Lampugnani ER, McCarthy MA, Jacobs SJ, Pezza AB, Newbigin EJ. Seasonal asthma in Melbourne, Australia, and some observations on the occurrence of thunderstorm asthma and its predictability. PLoS One 2018; 13: e0194929.

30. Hew M, Lee J, Susanto NH, Prasad S, Bardin PG, Barnes S, Ruane L, Southcott AM, Gillman A, Young A, Rangamuwa K, O'Hehir RE, McDonald C, Sutherland M, Conron M, Matthews S, Harun NS, Lachapelle P, Douglass JA, Irving L, Langton D, Mann J, Erbas B, Thien F. The 2016 Melbourne thunderstorm asthma epidemic: risk factors for severe attacks requiring hospital admission.

Allergy 2018.

31. Andrew E, Nehme Z, Bernard S, Abramson MJ, Newbigin E, Piper B, Dunlop J, Holman P, Smith $K$. Stormy weather: a retrospective analysis of demand for emergency medical services during epidemic thunderstorm asthma. Bmj 2017; 359: j5636.

32. Wark PAB, Simpson JL, Hensley M, Gibson PG. Airway inflammation in thunderstorm asthma. Clin Exp Allergy 2002; 32: 1750-1756. 
33. Haselkorn T, Zeiger RS, Chipps BE, Mink DR, Szefler SJ, Simons FE, Massanari M, Fish JE. Recent asthma exacerbations predict future exacerbations in children with severe or difficult-to-treat asthma. J Allergy Clin Immunol 2009; 124: 921-927.

34. Chipps BE, Zeiger RS, Dorenbaum A, Borish L, Wenzel SE, Miller DP, Hayden ML, Bleecker ER, Simons FE, Szefler SJ, Weiss ST, Haselkorn T, Group TS. Assessment of asthma control and asthma exacerbations in the epidemiology and natural history of asthma: outcomes and treatment regimens (TENOR) observational cohort. Curr Respir Care Rep 2012; 1: 259-269.

35. Covar RA, Szefler SJ, Zeiger RS, Sorkness CA, Moss M, Mauger DT, Boehmer SJ, Strunk RC, Martinez FD, Taussig LM, Childhood Asthma R, Education N. Factors associated with asthma exacerbations during a long-term clinical trial of controller medications in children. J Allergy Clin Immunol 2008; 122: 741-747 e744.

36. Teach SJ, Gergen PJ, Szefler SJ, Mitchell HE, Calatroni A, Wildfire J, Bloomberg GR, Kercsmar CM, Liu AH, Makhija MM, Matsui E, Morgan W, O'Connor G, Busse WW. Seasonal risk factors for asthma exacerbations among inner-city children. J Allergy Clin Immunol 2015; 135: 1465-1473 e1465.

37. Bateman ED, Buhl R, O'Byrne PM, Humbert M, Reddel HK, Sears MR, Jenkins C, Harrison TW, Quirce S, Peterson S, Eriksson G. Development and validation of a novel risk score for asthma exacerbations: The risk score for exacerbations. J Allergy Clin Immunol 2015; 135: 1457-1464 e1454.

38. ten Brinke A, Sterk PJ, Masclee AA, Spinhoven P, Schmidt JT, Zwinderman AH, Rabe KF, Bel EH. Risk factors of frequent exacerbations in difficult-to-treat asthma. Eur Respir J 2005; 26: 812-818. 39. Yii ACA, Tan JHY, Lapperre TS, Chan AKW, Low SY, Ong TH, Tan KL, Chotirmall SH, Sterk PJ, Koh MS. Long-term future risk of severe exacerbations: Distinct 5-year trajectories of problematic asthma. Allergy 2017; 72: 1398-1405.

40. McDonald VM, Hiles SA, Godbout K, Harvey ES, Marks GB, Hew M, Peters M, Bardin PG, Reynolds PN, Upham JW, Baraket M, Bhikoo Z, Bowden J, Brockway B, Chung LP, Cochrane B, Foxley G, Garrett J, Jayaram L, Jenkins C, Katelaris C, Katsoulotos G, Koh MS, Kritikos V, Lambert M, Langton D, Lara Rivero A, Middleton PG, Nanguzgambo A, Radhakrishna N, Reddel H, Rimmer J, Southcott AM, Sutherland M, Thien F, Wark PAB, Yang IA, Yap E, Gibson PG. Treatable traits can be identified in a severe asthma registry and predict future exacerbations. Respirology 2018. 41. Kupczyk M, ten Brinke A, Sterk PJ, Bel EH, Papi A, Chanez P, Nizankowska-Mogilnicka E, Gjomarkaj M, Gaga M, Brusselle G, Dahlen B, Dahlen SE. Frequent exacerbators--a distinct phenotype of severe asthma. Clin Exp Allergy 2014; 44: 212-221.

42. Amelink M, de Groot JC, de Nijs SB, Lutter R, Zwinderman AH, Sterk PJ, ten Brinke A, Bel EH. Severe adult-onset asthma: A distinct phenotype. J Allergy Clin Immunol 2013; 132: 336-341. 43. Wagener AH, de Nijs SB, Lutter R, Sousa AR, Weersink EJ, Bel EH, Sterk PJ. External validation of blood eosinophils, $\mathrm{FE}(\mathrm{NO})$ and serum periostin as surrogates for sputum eosinophils in asthma. Thorax 2015; 70: 115-120.

44. Zeiger RS, Schatz M, Li Q, Chen W, Khatry DB, Gossage D, Tran TN. High blood eosinophil count is a risk factor for future asthma exacerbations in adult persistent asthma. J Allergy Clin Immunol Pract 2014; 2: 741-750.

45. Zeiger RS, Schatz M, Dalal AA, Chen W, Sadikova E, Suruki RY, Kawatkar AA, Qian L. Blood Eosinophil Count and Outcomes in Severe Uncontrolled Asthma: A Prospective Study. J Allergy Clin Immunol Pract 2017; 5: 144-153 e148.

46. Casciano J, Krishnan JA, Small MB, Buck PO, Gopalan G, Li C, Kemp R, Dotiwala Z. Burden of asthma with elevated blood eosinophil levels. BMC Pulm Med 2016; 16: 100.

47. Malinovschi A, Janson C, Borres M, Alving K. Simultaneously increased fraction of exhaled nitric oxide levels and blood eosinophil counts relate to increased asthma morbidity. J Allergy Clin Immunol 2016; 138: 1301-1308 e1302. 
48. Agache I, Rogozea L. Endotypes in allergic diseases. Curr Opin Allergy Clin Immunol 2018; 18 : 177-183.

49. Wark PA, Johnston SL, Moric I, Simpson JL, Hensley MJ, Gibson PG. Neutrophil degranulation and cell lysis is associated with clinical severity in virus-induced asthma. Eur Respir J 2002; 19: 6875.

50. Wang F, He XY, Baines KJ, Gunawardhana LP, Simpson JL, Li F, Gibson PG. Different inflammatory phenotypes in adults and children with acute asthma. Eur Respir J 2011; 38: 567574.

51. Simpson JL, Grissell TV, Douwes J, Scott RJ, Boyle MJ, Gibson PG. Innate immune activation in neutrophilic asthma and bronchiectasis. Thorax 2007; 62: 211-218.

52. Baines KJ, Simpson JL, Wood LG, Scott RJ, Fibbens NL, Powell H, Cowan DC, Taylor DR, Cowan JO, Gibson PG. Sputum gene expression signature of 6 biomarkers discriminates asthma inflammatory phenotypes. J Allergy Clin Immunol 2014; 133: 997-1007.

53. Kim RY, Horvat JC, Pinkerton JW, Starkey MR, Essilfie AT, Mayall JR, Nair PM, Hansbro NG, Jones B, Haw TJ, Sunkara KP, Nguyen TH, Jarnicki AG, Keely S, Mattes J, Adcock IM, Foster PS, Hansbro PM. MicroRNA-21 drives severe, steroid-insensitive experimental asthma by amplifying phosphoinositide 3-kinase-mediated suppression of histone deacetylase 2. J Allergy Clin Immunol 2017; 139: 519-532.

54. Kim RY, Pinkerton JW, Essilfie AT, Robertson AAB, Baines KJ, Brown AC, Mayall JR, Ali MK, Starkey MR, Hansbro NG, Hirota JA, Wood LG, Simpson JL, Knight DA, Wark PA, Gibson PG, O'Neill LAJ, Cooper MA, Horvat JC, Hansbro PM. Role for NLRP3 Inflammasome-mediated, IL-1betaDependent Responses in Severe, Steroid-Resistant Asthma. Am J Respir Crit Care Med 2017; 196: 283-297.

55. Loymans RJ, Gemperli A, Cohen J, Rubinstein SM, Sterk PJ, Reddel HK, Juni P, ter Riet G. Comparative effectiveness of long term drug treatment strategies to prevent asthma exacerbations: network meta-analysis. BMJ 2014; 348: g3009.

56. Parameswaran K, O'Byrne PM, Sears MR. Inhaled corticosteroids for asthma: common clinical quandaries. J Asthma 2003; 40: 107-118.

57. Suissa S, Ernst P, Benayoun S, Baltzan M, Cai B. Low-dose inhaled corticosteroids and the prevention of death from asthma. N Engl J Med 2000; 343: 332-336.

58. Green RH, Brightling CE, McKenna S, Hargadon B, Parker D, Bradding $P$, al e. Asthma exacerbations and sputum eosinophil counts: a randomised control trial. Lancet 2002; 360: 17151721.

59. Jayaram L, Pizzichini MM, Cook RJ. Determining asthma treatment by monitoring sputum cell counts: effect on exacerbation. Eur Respir J 2006; 27: 483-494.

60. Rodrigo GJ, Neffen $\mathrm{H}$. Systematic review on the use of omalizumab for the treatment of asthmatic children and adolescents. Pediatr Allergy Immunol 2015; 26: 551-556.

61. Farne HA, Wilson A, Powell C, Bax L, Milan SJ. Anti-IL5 therapies for asthma. Cochrane Database Syst Rev 2017; 9: Cd010834.

62. Castro M, Corren J, Pavord ID, Maspero J, Wenzel S, Rabe KF, Busse WW, Ford L, Sher L, FitzGerald JM, Katelaris C, Tohda Y, Zhang B, Staudinger H, Pirozzi G, Amin N, Ruddy M, Akinlade B, Khan A, Chao J, Martincova R, Graham NMH, Hamilton JD, Swanson BN, Stahl N, Yancopoulos GD, Teper A. Dupilumab Efficacy and Safety in Moderate-to-Severe Uncontrolled Asthma. N Engl J Med 2018; 378: 2486-2496.

63. Rabe KF, Nair P, Brusselle G, Maspero JF, Castro M, Sher L, Zhu H, Hamilton JD, Swanson BN, Khan A, Chao J, Staudinger H, Pirozzi G, Antoni C, Amin N, Ruddy M, Akinlade B, Graham NMH, Stahl N, Yancopoulos GD, Teper A. Efficacy and Safety of Dupilumab in Glucocorticoid-Dependent Severe Asthma. N Engl J Med 2018; 378: 2475-2485. 
64. Kirkland SW, Vandermeer B, Campbell S, Villa-Roel C, Newton A, Ducharme FM, Rowe BH. Evaluating the effectiveness of systemic corticosteroids to mitigate relapse in children assessed and treated for acute asthma: A network meta-analysis. J Asthma 2018: 1-12.

65. Rowe BH, Kirkland SW, Vandermeer B, Campbell S, Newton A, Ducharme FM, Villa-Roel C. Prioritizing Systemic Corticosteroid Treatments to Mitigate Relapse in Adults With Acute Asthma: A Systematic Review and Network Meta-analysis. Acad Emerg Med 2017; 24: 371-381.

66. Edmonds ML, Milan SJ, Camargo CA, Jr., Pollack CV, Rowe BH. Early use of inhaled corticosteroids in the emergency department treatment of acute asthma. Cochrane Database Syst Rev 2012; 12: Cd002308.

67. Quon BS, Fitzgerald JM, Lemiere C, Shahidi N, Ducharme FM. Increased versus stable doses of inhaled corticosteroids for exacerbations of chronic asthma in adults and children. Cochrane Database Syst Rev 2010: Cd007524.

68. Oborne J, Mortimer K, Hubbard RB, Tattersfield AE, Harrison TW. Quadrupling the dose of inhaled corticosteroid to prevent asthma exacerbations: a randomized, double-blind, placebocontrolled, parallel-group clinical trial. Am J Respir Crit Care Med 2009; 180: 598-602.

69. Haughney J, Sears MR. The application of budesonide/formoterol (Symbicort ${ }^{\circledR}$ ) adjustable maintenance dosing to real-life clinical practice. International Journal of Clinical Practice 2004; 58 : 42-46.

70. Cheung D, van Klink HC, Aalbers R. Improved lung function and symptom control with formoterol on demand in asthma. Eur Respir J 2006; 27: 504-510.

71. Fitzgerald JM, Olsson P, Michils A. Adjustable maintenance dosing with budesonide/formoterol in a single inhaler - efficacy and safety. International Journal of Clinical Practice 2004; 58: 18-25. 72. O'Byrne PM, FitzGerald JM, Bateman ED, Barnes PJ, Zhong N, Keen C, Jorup C, Lamarca R, Ivanov S, Reddel HK. Inhaled Combined Budesonide-Formoterol as Needed in Mild Asthma. N Engl J Med 2018; 378: 1865-1876.

73. Bateman ED, Reddel HK, O'Byrne PM, Barnes PJ, Zhong N, Keen C, Jorup C, Lamarca R, SiwekPosluszna A, FitzGerald JM. As-Needed Budesonide-Formoterol versus Maintenance Budesonide in Mild Asthma. N Engl J Med 2018; 378: 1877-1887.

74. Rowe BH, Spooner C, Ducharme F, Bretzlaff J, Bota G. Corticosteroids for preventing relapse following acute exacerbations of asthma. Cochrane Database of Systematic Reviews 2007.

75. Ramsahai JM, Wark P. Appropriate use of oral corticosteroids in severe asthma. Med J Aust 2018; 209: S18-S21.

76. Gibson PG, Powell H. Written action plans for asthma: an evidence-based review of the key components. Thorax 2004; 59: 94-99.

77. Mclvor RA, Pizzichini E, Turner MO, Hussack P, Hargreave FE, Sears MR. Potential masking effects of salmeterol on airway inflammation in asthma. Am J Respir Crit Care Med 1998; 158: 924930.

78. Rogers L, Hanania NA. Role of anticholinergics in asthma management: recent evidence and future needs. Current Opinion in Pulmonary Medicine 2015; 21: 103-108.

79. Waldeck B. $\beta$-Adrenoceptor agonists and asthma-100 years of development. European Journal of Pharmacology 2002; 445: 1-12.

80. Reed BN, Zhang S, Marron JS, Montague D. Comparison of intravenous and oral magnesium replacement in hospitalized patients with cardiovascular disease. Am J Health Syst Pharm 2012; 69: 1212-1217.

81. Kew KM, Kirtchuk L, Michell $\mathrm{Cl}$. Intravenous magnesium sulfate for treating adults with acute asthma in the emergency department. Cochrane Database Syst Rev 2014: Cd010909.

82. Ling ZG, Wu YB, Kong JL, Tang ZM, Liu W, Chen YQ. Lack of efficacy of nebulized magnesium sulfate in treating adult asthma: A meta-analysis of randomized controlled trials. Pulm Pharmacol Ther 2016; 41: 40-47. 
83. Powell C, Dwan K, Milan SJ, Beasley R, Hughes R, Knopp-Sihota JA, Rowe BH. Inhaled magnesium sulfate in the treatment of acute asthma. Cochrane Database Syst Rev 2012; 12: Cd003898.

84. Su Z, Li R, Gai Z. Intravenous and Nebulized Magnesium Sulfate for Treating Acute Asthma in Children: A Systematic Review and Meta-Analysis. Pediatr Emerg Care 2018; 34: 390-395.

85. Wark PAB, Johnston SL, Bucchieri F, Powell R, Puddicombe S, Laza-Stanca V, Holgate ST, Davies $D E$. Asthmatic bronchial epithelial cells have a deficient innate immune response to infection with rhinovirus. J Exp Med 2005; 201: 937-947.

86. Djukanovic R, Harrison T, Johnston SL, Gabbay F, Wark P, Thomson NC, Niven R, Singh D, Reddel HK, Davies DE, Marsden R, Boxall C, Dudley S, Plagnol V, Holgate ST, Monk P, Group IS. The effect of inhaled IFN-beta on worsening of asthma symptoms caused by viral infections. A randomized trial. Am J Respir Crit Care Med 2014; 190: 145-154.

87. Normansell R, Sayer B, Waterson S, Dennett EJ, Del Forno M, Dunleavy A. Antibiotics for exacerbations of asthma. Cochrane Database Syst Rev 2018; 6: Cd002741.

88. Johnston SL, Blasi F, Black PN, Martin RJ, Farrell DJ, Nieman RB. The effect of telithromycin in acute exacerbations of asthma. N Engl J Med 2006; 354: 1589-1600.

89. Johnston SL, Szigeti M, Cross M, Brightling C, Chaudhuri R, Harrison T, Mansur A, Robison L, Sattar Z, Jackson D, Mallia P, Wong E, Corrigan C, Higgins B, Ind P, Singh D, Thomson NC, Ashby D, Chauhan A, Team AT. Azithromycin for Acute Exacerbations of Asthma : The AZALEA Randomized Clinical Trial. JAMA Intern Med 2016; 176: 1630-1637.

90. Stokholm J, Chawes BL, Vissing NH, Bjarnadottir E, Pedersen TM, Vinding RK, Schoos AM, Wolsk HM, Thorsteinsdottir S, Hallas HW, Arianto L, Schjorring S, Krogfelt KA, Fischer TK, Pipper $\mathrm{CB}$, Bonnelykke K, Bisgaard H. Azithromycin for episodes with asthma-like symptoms in young children aged 1-3 years: a randomised, double-blind, placebo-controlled trial. Lancet Respir Med 2016; 4: 19-26.

91. Mandhane PJ, Paredes Zambrano de Silbernagel P, Aung YN, Williamson J, Lee BE, Spier S, Noseworthy M, Craig WR, Johnson DW. Treatment of preschool children presenting to the emergency department with wheeze with azithromycin: A placebo-controlled randomized trial. PLoS One 2017; 12: e0182411.

92. Gibson PG, Yang IA, Upham JW, Reynolds PN, Hodge S, James AL, Jenkins C, Peters MJ, Marks GB, Baraket M, Powell H, Taylor SL, Leong LEX, Rogers GB, Simpson JL. Effect of azithromycin on asthma exacerbations and quality of life in adults with persistent uncontrolled asthma (AMAZES): a randomised, double-blind, placebo-controlled trial. Lancet 2017; 390: 659-668.

93. Brusselle GG, Vanderstichele $C$, Jordens $P$, Deman R, Slabbynck $H$, Ringoet $V$, Verleden $G$, Demedts IK, Verhamme K, Delporte A, Demeyere B, Claeys G, Boelens J, Padalko E, Verschakelen J, Van Maele G, Deschepper E, Joos GF. Azithromycin for prevention of exacerbations in severe asthma (AZISAST): a multicentre randomised double-blind placebo-controlled trial. Thorax 2013; 68: 322-329.

94. Chari VM, Mclvor RA. Tiotropium for the Treatment of Asthma: Patient Selection and Perspectives. Can Respir J 2018; 2018: 3464960.

95. Gill MA, Liu AH, Calatroni A, Krouse RZ, Shao B, Schiltz A, Gern JE, Togias A, Busse WW. Enhanced plasmacytoid dendritic cell antiviral responses after omalizumab. J Allergy Clin Immunol 2018; 141: 1735-1743 e1739.

96. Busse WW, Holgate S, Kerwin E, Chon Y, Feng J, Lin J, Lin SL. Randomized, double-blind, placebo-controlled study of brodalumab, a human anti-IL-17 receptor monoclonal antibody, in moderate to severe asthma. Am J Respir Crit Care Med 2013; 188: 1294-1302.

97. Wenzel SE, Barnes PJ, Bleecker ER, Bousquet J, Busse W, Dahlen SE, Holgate ST, Meyers DA, Rabe KF, Antczak A, Baker J, Horvath I, Mark Z, Bernstein D, Kerwin E, Schlenker-Herceg R, Lo KH, Watt R, Barnathan ES, Chanez P. A randomized, double-blind, placebo-controlled study of tumor 
necrosis factor-alpha blockade in severe persistent asthma. Am J Respir Crit Care Med 2009; 179: 549-558.

98. De Alba J, Otal R, Calama E, Domenech A, Prats N, Gozzard N, Miralpeix M. Double-stranded RNA evokes exacerbation in a mouse model of corticosteroid refractory asthma. Clin Sci (Lond) 2015; 129: 973-987.

99. Teach SJ, Gill MA, Togias A, Sorkness CA, Arbes SJ, Jr., Calatroni A, Wildfire JJ, Gergen PJ, Cohen RT, Pongracic JA, Kercsmar CM, Khurana Hershey GK, Gruchalla RS, Liu AH, Zoratti EM, Kattan M, Grindle KA, Gern JE, Busse WW, Szefler SJ. Preseasonal treatment with either omalizumab or an inhaled corticosteroid boost to prevent fall asthma exacerbations. J Allergy Clin Immunol 2015; 136: 1476-1485.

100. Esquivel A, Busse WW, Calatroni A, Togias AG, Grindle KG, Bochkov YA, Gruchalla RS, Kattan M, Kercsmar CM, Khurana Hershey G, Kim H, Lebeau P, Liu AH, Szefler SJ, Teach SJ, West JB, Wildfire J, Pongracic JA, Gern JE. Effects of Omalizumab on Rhinovirus Infections, Illnesses, and Exacerbations of Asthma. Am J Respir Crit Care Med 2017; 196: 985-992.

101. Normansell R, Walker S, Milan SJ, Walters EH, Nair P. Omalizumab for asthma in adults and children. Cochrane Database Syst Rev 2014: CD003559.

102. Corren J, Parnes JR, Wang L, Mo M, Roseti SL, Griffiths JM, van der Merwe R. Tezepelumab in Adults with Uncontrolled Asthma. New England Journal of Medicine 2017; 377: 936-946. 